\title{
RACISMO RELIGIOSO CATÓLICO COLONIAL EN LA REGIÓN ANDINA: CONSECUENCIAS EN LA JUVENTUD AYMARA
}

\author{
COLONIAL CATHOLIC RELIGIOUS RACISM IN ANDEAN REGION: \\ CONSEQUENCES TO AYMARA YOUTH
}

\author{
Bartolomé Mamani-Humpiri \\ Instituto Peruano de Investigación JATHA MUHU \\ Puno-Perú \\ Alejandra Caqueo-Urízar* \\ Universidad de Tarapacá \\ Arica-Chile \\ Recibido septiembre de 2020/Received September, 2020 \\ Aceptado abril de 2021/Accepted April, 2021
}

\begin{abstract}
RESUMEN
El racismo en los Andes se conformó en la época colonial, pero no apunta directamente a la religión colonial como uno de los medios de construcción racial. Este estudio tiene como objetivo determinar la influencia de las creencias en las imágenes religiosas católicas coloniales de la "raza blanca" en la construcción del racismo en jóvenes del pueblo Aymara de Perú. La investigación cualitativa se llevó a cabo mediante la observación activa y participativa, entrevistas en profundidad y grupos de discusión en los diferentes espacios sociales de las poblaciones del pueblo Aymara. Además, se utilizaron datos de fuentes secundarias. Jóvenes Aymara idealizan los ídolos religiosos representados en la imaginería católica, tienden a identificar la "santidad" y el "poder" de los ídolos religiosos por su condición de blancos. Por esta razón, estos jóvenes están predispuestos a considerar a sus compañeros terrenales como "pecadores" y "débiles" debido a su estatus de "raza oscura".
\end{abstract}

Palabras Clave: Racismo, Religión, Aymara, Jóvenes, Investigación cualitativa.

\section{ABSTRACT}

Racism in the Andes was built in colonial times, but they do not directly point to colonial religion as one of the means of racial construction. This study aims to determine the influence of beliefs in colonial Catholic religious images of "white race" in the construction of racism in the young people of the Aymara people of Peru. Qualitative research was conducted through active participatory observation, in-depth interviews and focus groups in the different social spaces of the populations of the Aymara people. In addition, data from secondary sources were used. Aymara young, idealize the religious idols represented in Catholic imagery, tend to identify the "sanctity" and "power" of religious idols with their status as white people. For this reason, these young people are predisposed to consider their fellow earthling's "sinners" and "weak" because of their status as "dark race".

Key Words: Racism, Religion, Aymara, Young people, Qualitative research. 


\section{AGRADECIMIENTOS}

Este estudio ha sido asesorado por los profesores Miguel A. Sobrino y Coral Hernández de la UCM, se contó con el apoyo del personal del Instituto JATHA-MUHU y de seis profesionales de antropología y sociología colaboradores en diferentes etapas de la investigación, fundamentalmente queremos agradecer a los informantes de los tres centros poblados Aymara. Finalmente, queremos agradecer a la Fundación Ford por haber financiado una beca al primer autor de la presente investigación.

\section{INTRODUCCIÓN}

El pueblo Aymara se remonta a tiempos inmemoriales, formando parte inseparable de la “construcción" de la cultura Andina (Murra, 1987). El principal territorio de los Aymara ha sido y sigue siendo el circundante al lago Titikaka, pero el área territorial ancestral de este pueblo abarca el Sur del Perú, una parte Occidental de Bolivia, Norte de Chile y Norte de Argentina.

En ese sentido, las matrices del nacimiento del pueblo Aymara como una cultura que avanzó en diferentes campos del desarrollo humano y luego influyó en el surgimiento y desarrollo de la cultura incaica, según Galindo et al. (2007) citando a los arqueólogos Bennet, Rowe y Ravines, están en otras culturas que existieron antes de la cultura Tiwanaku. No obstante, el idioma Aymara surgiría de la influencia mutua de dos culturas: Wari (800 a 1200 d. C.) y Tiwanaku (500 a 1000 d. C.) (Llanque, 1990).

Después de la ruina del estado Tiwanaku, en el altiplano surgieron los "señoríos Aymara" (Llanque, 1990). En el gobierno de Mayta Capac se inicia la conquista de los reinos Aymara, cuya expansión incaica se desarrolla por la vía diplomática y por la vía militar. En ese sentido, el historiador Klauer (2000, p. 83) afirma que, si bien es cierto que los gobernantes incas trataron de imponer a los pueblos conquistados como a los Aymara "los más variados aspectos de su cultura" (costumbres, religión, idioma, etc.) aplicando diferentes estrategias; sin embargo, estos pueblos no renunciaron a sus nacionalidades, dentro de las que están sus particularidades religiosas.

En 1532 se produce la llegada abrupta de las huestes de los colonizadores españoles, donde estaban también los representantes de la Iglesia Católica, como el sacerdote Hernando de Luque (financista y socio de Francisco Pizarro) y fray Vicente de
Valverde (Vinatea, 2018). Según Mendieta (s.f.), la religión católica, para los europeos, es una de las tecnologías más importantes de poder en Occidente. En ese propósito, los colonizadores españoles utilizaron a la religión católica como "arma letal" para el proceso de "desmantelamiento" de la estructura social y cultural de los pueblos andinos.

La convergencia entre el Estado y la Iglesia Católica se afianzó en el siglo IV, cuando el emperador romano Constantino convocó al concilio de Nicea I con el fin de pacificar y unificar a su imperio (Rossi, 2015). Desde esa época, según Ullmann (1993), los "cristianos católicos" confluyen y se convierten en actores del sistema imperial romano (citado en Rossi 2015, p. 44). Es decir, los católicos pasan a ser la representante y heredera de la antigua cultura Romana y con ello pervirtieron los principios cristianos registrados en las Santas Escrituras (Marcos 7: 6-13; Dawson, 1970; Caro, 1985; Weber, 2007).

Ya que el propio fundador del cristianismo, Jesucristo, rehusó involucrarse con los representantes del Imperio Romano y de los judíos, afirmando que su "reino no es parte de este mundo" (Juan 15: 19; 18: 36). Además, Jesucristo profetizó que sus seguidores no serían parte de los gobiernos terrenales, más bien les comisionó la tarea de evangelización en "todas las naciones" para su futuro reino (Lucas 21: 12; Mateo 28: 18-20).

Los españoles católicos, por el contrario, vinieron a América en busca de riquezas y utilizaron la religión católica para dominar a las poblaciones originarias (Guaman Poma, 1993). Así, los sacerdotes católicos en sus jurisdicciones obligaban a las personas originarias a realizar fiestas patronales y otras prácticas en honor a las imágenes religiosas (propias de las religiones paganas romanas y griegas) para sacar réditos económicos (Robins, 2009). Estas imágenes consideradas divinas representaban la belleza ideal católica similares a los ídolos grecorromanos (Caro, 1985).

Las veneraciones de las imágenes en las Santas Escrituras (antiguo y nuevo testamento) son consideradas idolatrías o contrarias a la adoración pura a Dios (Éxodo 34: 17; Números 33: 52; Deuteronomio 7: 5; 1 Reyes 14: 9-11). El propio Jesucristo manifestó que "a Jehová tu Dios a quien tienes que adorar y es solo a él...", además, dijo que "Dios es un Espíritu (no una imagen material) y los que lo adoran tienen que adorarlo con espíritu y con verdad" (Mateo 4: 10, Juan 4: 24). Después 
de la muerte de Jesucristo, el apóstol Pablo exhortó a los que ya profesaban ser cristianos en muchas naciones europeas a adorar a "un solo Dios el Padre" $\mathrm{y}$ tener como modelo en sentido espiritual y moral a Jesucristo (1 Corintios 8: 5-6; 11:1).

Por ello, en el primer siglo en Europa o después de la muerte de Jesucristo, los oprimidos por el imperio Romano, según Dawson (1970, p. 53), al abstraer las doctrinas cristianas se liberaron y se convirtieron en los "más fuertes y animosos en la vida de aquel tiempo". En la Edad Media, los protestantes de los países nórdicos europeos también reivindicaron los preceptos de las Santas Escrituras y lucharon tanto por liberarse de la corrupción y la tradición católica como de la veneración de las imágenes (Weber, 2007).

Los clérigos apoyados con el poder colonial español, sin embargo, ejecutaron un proceso de extirpación de idolatrías o de los "Dioses Andinos", en los mismos lugares "sagrados Andinos" sobrepusieron a los ídolos católicos de "raza blanca" como instrumentos de dominación; e implementaron la catolización forzosa de las poblaciones originarias (Rostworowski, 1983; Montoya, 1990). Al respecto, el sacerdote católico y Rector de la Universidad Católica Boliviana "San Pablo" de Bolivia, Hans van den Berg (2005), afirma que una imagen católica (ídolo) era denominada como dueña sobrenatural ("santa patrona de" o "santo patrono de") de una población originaria determinada.

En este ambiente de prácticas religiosas, a finales del siglo XIX, Manuel Z. Camacho, de origen del pueblo Aymara, crea la primera escuela clandestina en la parcialidad de Utawilaya (ubicado en el actual distrito de Platería en la región Puno, Perú) para Aymara adultos y luego amplió para niños/ as Aymara con el fin de enseñarles lectoescritura, higiene personal y acerca de agricultura para que no siguieran siendo explotados. Sin embargo, ante los constantes ataques violentos de la Iglesia Católica y de las autoridades civiles, Camacho busca el apoyo de instituciones que pudieran respaldar su iniciativa, en Lima se contacta con los representantes de la "Iglesia Adventista del Séptimo Día", a raíz de varios contactos y gestiones, finalmente en 1909 llega a Utawilaya el pastor Fernando Stahl; luego Camacho al bautizarse como adventista junto con el pastor empieza a organizar la educación básica para los Aymara y la labor de evangelización en diferentes pueblos Aymara (Núñez, 2008). Pese a los ataques de los clérigos católicos, Stahl llegó a los pueblos
Aymara más alejados como a los centros poblados de Umuchi, Quellahuyo Pomaoca y Occopampa de la actual provincia de Moho (zonas considerados en el presente estudio), donde encontró a los Aymara enfermos en completa "miseria e ignorancia"; el pastor, sin ser médico, al ser testigo de la agonía de los Aymara enfermos se dedicó a curarlos sin dejar su labor misional adventista, y muchos Aymara al bautizarse como adventistas dejaron de adorar a las imágenes católicas, la adicción al alcohol y la coca y mejoraron su aspecto personal; además, aprendieron a leer y escribir (Stahl, 2009). Ante esta realidad, la Iglesia Católica atacó constantemente a los Aymara conversos al adventismo porque estos ya no adoraban a las imágenes ni bebían alcohol que iba en desmedro de la economía de la Iglesia Católica. En la actualidad existen iglesias y escuelas o colegios adventistas en muchos pueblos Aymara y Quechuas en la región de Puno.

Considerando el análisis de los antecedentes expuestos, surge la siguiente pregunta de investigación: ¿Qué efectos tuvo o tiene en las personalidades de los feligreses en general, especialmente de los andinos, las creencias sincréticas católicas coloniales? En ese sentido, se emprendió la búsqueda bibliográfica de este problema. En un primer momento se analizó el libro Los orígenes de Europa de Christopher Dawson, quien se refiere a la liberación de los oprimidos romanos de las religiones paganas por medio de las Santas Escrituras y por tanto del poder del Imperio Romano.

Posteriormente después de varios textos revisados no se encontró investigaciones específicas del problema de estudio planteado. Solamente se localizó una página web, donde el historiador chileno Jorge Muzan (s. f.) relata su experiencia en tres párrafos, quien afirma que en su niñez al frecuentar con sus padres las iglesias católicas ha podido contemplar "bellas estatuas de yeso y las pinturas" de diferentes "santos o santas" semejantes a personas de "raza blanca" como Brad Pitt. Luego, como historiador concluyó que Jesús era moreno (por ser de origen semita), es decir, no era como se representa en aquellas imágenes que impregnaron su experiencia infantil.

Si bien es cierto que en algunos textos referidos a racismo en América Latina coinciden en afirmar que la causa principal de las prácticas de discriminación y los prejuicios racistas está en el colonialismo (superioridad/inferioridad), no aluden a las imágenes y creencias católicas coloniales como 
modelos racistas fenotípicos ni los efectos en las personalidades de los feligreses como se visualizará en el presente estudio.

En resumen, este estudio tiene como objetivo describir la tendencia de la línea matriz de las creencias católicas coloniales que ha perpetuado la "superioridad de la raza blanca" y cómo estas permanecen en el imaginario colectivo como una fuerza reguladora de las estructuras actitudinales y comportamentales de los pueblos, en cada uno de ellos con sus matices particulares.

\section{ESTADO DE ARTE}

Múltiples estudios realizados en Europa, España, América Latina, Perú y también algunos textos tratan hechos religiosos de la época colonial y a inicios de la republicana; sin embargo, en la siguiente revisión se han incluido los textos o estudios más relevantes para el desarrollo de la presente temática.

En ese sentido, la Oficina del Alto Comisionado de las Naciones Unidas para los Derechos Humanos (ACNUDH, 2003) publicó estudios de expertos de diferentes campos del conocimiento que pertenecen a instituciones que se ocupan de racismo a nivel global, quienes destacaron acerca del racismo institucionalizado y estructural en las diferentes sociedades, donde las normas o costumbres colectivas que legitiman la intolerancia racial en todos los campos de desarrollo humano (educación, salud, administración de justicia, campo laboral, medios de comunicación, etc.).

Entretanto, Quijano (1992) para su ensayo efectuó una investigación bibliográfica donde afirma que el concepto de "raza" se utiliza para categorizar a las diferentes poblaciones y para organizar la estructura del poder en un ambiente sistemático de brutal represión y genocidio desde la invasión de América por los españoles. El autor para explicar sus hipótesis acuña el término "colonización del imaginario de los dominados" por medio de las creencias e imágenes coloniales, y en la posterioridad sigue ejerciendo poder en el mundo interior de los colonizados.

Los autores españoles ilustran desde la visión de los colonizadores de los hechos religiosos producidos en España de la Edad Media como también en América colonial. Caro (1985), en la revisión y análisis de una variedad de textos históricos acerca de la religión en España de los siglos XVI y XVII, considera que la religión católica es el principal factor de la formación histórica de identidad española en un ambiente de represión, donde la adoración de imágenes religiosas (perfección moral y espiritual) era la parte importante de los ritos católicos, porque estas representaban a seres divinos "superiores" y a la "suprema belleza". Entonces, a partir de estas idealizaciones (suprema belleza), los clérigos católicos valoraban y categorizaban a los ídolos de los territorios conquistados en América. Así, el autor refiere que, para el cura Esteban de Salazar en 1564: que "todas las figuras de los ídolos (de las poblaciones originarias) americanos eran horrendas y abominables frente a lo que ocurría con las imágenes de los dioses griegos y romanos que eran bellos" (Caro, 1984).

También del Olmo (2003), al estudiar los textos históricos, especialmente religiosos, para ahondar en el fenómeno del racismo desde la perspectiva religiosa, afirma que el concepto de la "limpieza de sangre" se introduce a finales del siglo XV por los católicos para garantizar la "pureza de sangre" de sus feligreses. Con este "ideal" discriminaban a los judíos o musulmanes, supuestamente por su "impureza de sangre" y por su color de piel oscuro, presuntamente a base de las Santas Escrituras (Éxodo 34: 16; Deuteronomio 7: 3; 23: 2-4; Esdras 9: 2); por ello, el autor denomina este concepto como "racismo cristiano-biológico"1. No obstante, al revisar los mencionados textos bíblicos eran disposiciones para prevenir la infiltración del paganismo en el pueblo de Israel y no perder la armonía de convivencia humana basada en los diez mandamientos; por ende, la adoración pura al Dios invisible (Juan 4: 24; Levítico 19: 14-19). Además, en algunos textos bíblicos se refiere a la ropa blanca como símbolo de santidad del alma (pureza moral y espiritual) y no de la piel humana (Revelación 3:4; 6: 11; 7: 9-13; Mateo 28: 2-4).

En la investigación titulada "Inquisición y Limpieza de Sangre en Nueva España: 1571-1623" de la Universidad Cantabria-España, Suárez (2012), realizó una revisión de textos del Tribunal de Santo Oficio en Nueva España que fue instalado en 1571, entre otros, acerca de la limpieza de sangre en México, concluyendo que el mencionado Tribunal tenía la misión de velar por la fe católica en México porque los católicos ibéricos creían que por medio de la sangre circulaban los valores y costumbres religiosos. Sin embargo, en Latinoamérica en el proceso de mestizaje adquiere mayor preponderancia el color de la piel que la "pureza de sangre"; de tal manera, 
lo "blanco" es tomado como "pureza y calidad" y lo "no blanco" es la "impureza" (Suárez, 2012, p. 21).

Entretanto, los autores de América Latina o de otros países muestran el proceso de colonización religiosa española y las consecuencias de las mismas. Al respecto, Sánchez (2003) investigó el esclarecimiento del mensaje iconográfico (significado de la imagen) en los catecismos pictográficos del siglo XVI. La autora en el marco teórico destaca que, en el siglo XVI, la Iglesia Católica dispuso la creación artística de las imágenes religiosas para representar la "santidad". En el presente estudio se concluye que los clérigos católicos en México fundaron los "Colegios de Artes y Oficios de Fray Pedro de Gante ó Escuelas Conventuales" con la finalidad de instruir a las personas originarias para producir imágenes religiosas; las mismas consideradas como "santas" servían para catequizar a los pobladores originarios.

En ese sentido, en el análisis del discurso de las imágenes religiosas católicas de Nueva Granada del siglo XVII, Carrión (2006) ${ }^{2}$ determinó acerca de cómo son representados los colonizados dentro de las imágenes religiosas y la relación que existe entre estas imágenes y la "construcción de identidad de los sujetos colonizados", en Nueva Granada del siglo XVII en Colombia. La autora comprobó que los colonizadores católicos también llevaron su lucha al campo de representaciones mentales (capturar a los sujetos) a base de las imágenes religiosas coloniales de "raza blanca" para la construcción de las identidades raciales históricas bajo la estructura del estereotipo colonial y naturalizar la dominación en Colombia ${ }^{3}$. Además, según Carrión (2006), estos ídolos coloniales se introdujeron para formar y ajustar el arquetipo de victoria sobre el pecado; como ilustra la imagen de "San Santiago" (pasa de "matamoros" a "mataindios") montado sobre un caballo blanco en la parte superior (simboliza la cabalgadura de los dioses), pisando a los vencidos (pueblos originarios) maléficos en la parte inferior. De modo que, según Wachtel (1976), quien por medio de la "etnohistoria", afirma que los traumas de la conquista están profundamente inscritos en las estructuras mentales colectivas de las poblaciones originarias de América Latina del siglo XX que se visualizan en las prácticas folclóricas (festividades) de las mismas poblaciones. Se ha podido verificar la existencia de hechos religiosos registrados en algunos textos de las zonas consideradas en el presente estudio. Robins (2009) ${ }^{4}$, quien estudió las relaciones entre los clérigos católicos y los pobladores originarios en Alto Perú en el periodo de 1750 a 1780, en este periodo colonial a los pueblos del presente estudio los sacerdotes coloniales obligaban a los Aymara a participar y sufragar los costes de algunas fiestas patronales. De esta forma, los Aymara entregaban a los clérigos la materia prima (cera) con la que los curas elaboraban velas para luego venderlas a los mismos donantes para los ritos de adoración a los ídolos de "raza blanca". Por estos abusos, los pobladores de la zona de estudio presentaron ciertas quejas a las autoridades coloniales argumentando que los sacerdotes no les enseñaban de las Santas Escrituras, pero les obligaban a realizar fiestas y a casarse (Robins, 2009).

En las primeras décadas del siglo XX, el predicador adventista Stahl (2009) en su memoria ha registrado que los sacerdotes les mantenían a los Aymara, de las zonas del presente estudio, en completo estado de miseria e ignorancia. Por ello, Stahl ayudó a convertirse al adventismo a muchos Aymara, por lo que los curas comenzaron a atacar a los adventistas conversos y al mismo predicador. Para ilustrar, en una ocasión un cura acompañado de tres hombres obligó al convertido al adventismo, Juan Huanca, a participar en las fiestas patronales, pero este se negó; entonces, el sacerdote junto con sus acompañantes lo masacraron y lo dejaron en estado de agonía (Sthal, 2009).

\section{MARCO TEÓRICO}

\section{La adolescencia y la juventud: identidad social y racial}

Adolescentes y jóvenes están en una etapa de proceso no solamente en el sentido físico, sino también en lo emocional y comportamental condicionado por el ambiente sociocultural e histórico (Papalia, Wendkos y Duskin, 2009; Strocka, 2008). En las zonas del presente estudio, jóvenes que viven en un ambiente de pobreza generalizada sobre todo en el aspecto educativo, ya que la educación formal es de baja calidad y los padres de familia siguen arrastrando una tradición de la cultura colonial en relación con sus hijos/as (Mamani, 2003, 2004).

Desde la perspectiva psicológica social y sociológica, la identidad es considerada como constructo social, que está posicionada en lo interno de la personalidad del sujeto social y este está en constante interacción con lo externo o con la herencia sociocultural, que es producto del legado histórico, que pervive para marcar su pertenencia a 
una determinada sociedad (Strocka, 2008; Bourdieu, 2006).

Sin embargo, según Erikson, estos jóvenes se enfrentan a la crisis de la identidad en tres aspectos: la elección de una ocupación, la adoptación de los valores con los que vivirán y el desarrollo de una identidad sexual satisfactorio (citado en Papalia, Wendkos y Duskin, 2009, pp. 515, 546). Un estudio de identidad racial llevado a cabo por Kennerth Clark junto con su equipo de investigación observó cómo los niños de raza negra se inclinaban por juguetes caracterizados en la raza blanca (muñecas), lo que asoció al rechazo de su formación identitaria racial y étnico desde temprana edad con posibles efectos perjudiciales (baja autoestima) (citado en Baron y Byrne, 2005, p. 247).

\section{Representaciones mentales o imaginarios colectivos}

Este estudio se fundamenta en el enfoque social considerando a las poblaciones originarias; es decir, sin lo social no podría existir ni tendría sentido lo individual y así recíprocamente. En ese sentido, los conceptos de representaciones mentales e imaginarios colectivos son complementarios para estudiar o comprender los fenómenos históricos socioculturales.

Por consiguiente, se entiende por representaciones mentales como aprehensiones cognitivas que hacen los sujetos sociales del ambiente sociocultural e histórico (relación mente humana con la realidad); estas acciones intelectuales impactan en la construcción de la personalidad de los individuos (autoconcepto, identidad, formas de actuar). Sin embargo, los seres humanos no aprehenden el conjunto de la realidad existente, por lo que estas se denominan "subjetivas" (percepción y valoración parcial) (Castellaro, 2011; Vera, 2018).

Los imaginarios colectivos están constituidos por un conjunto de formas e imágenes socialmente construidos, que simbolizan a las realidades histórico sociocultural complejas (creencias, valores, etc.) del pasado, personificada en instituciones (conciencia colectiva) que evocan significaciones para regular o dar sentido a la vida individual o colectiva de una determinada sociedad (Maric, 2018; Uribe, Ramírez, Aliaga y Rojas, 2018).

\section{Religión y creencias religiosas}

La religión se entiende como un sistema de creencias en objetos o seres que son considerados sagrados, sobrenaturales o divinas y a los creyentes también les unen las prácticas rituales, por tanto, el resto (objetos o seres) está en el campo de lo profano (marginal); además, la religión también proporciona una cosmovisión del universo para dar sentido a la vida humana (Eliade, 1981; Durkheim, 1968; Geertz, 1965).

Peirce afirma que "la fuerza del hábito hará a veces que el hombre se aferre a sus viejas creencias" (citado en Fernández, 2007, p. 18). Además, el autor refiere que están imbricados la noción, el hábito-creencia y la acción. En consecuencia, las creencias religiosas son representaciones sociales (aprehendidas por los individuos) de las cosas sagradas para orientar la acción; donde la fe cumple un papel esencial en ese propósito, ya que esta se fundamenta en la manifestación de la existencia viva de las mismas (divinidades) como poderosos que norman, regulan y guían la convivencia humana, razón por la que los creyentes se apegan con fuerte componente emocional (Durkheim, 1968; Hervieu-Léger, 2005; Silva, Corona y Herrera, 2017; Fernández, 2007).

\section{Sincretismo y tecnología de poder}

El sincretismo religioso se entiende como la mezcla de varias creencias religiosas cuando empiezan a cohabitar entre los miembros de diferentes pueblos con dioses distintos. La religión romana es el ejemplo de sincretismo por la tolerancia a las creencias religiosas de las naciones conquistadas; además, se buscaba la unidad religiosa en el imperio, por ello, los dioses de las naciones conquistadas se fusionaban con sus dioses del imperio especialmente los ídolos griegos por ciertas similitudes con los romanos (Dawson, 1970; Caro, 1985). Luego, en el siglo IV se empezó a formar el carácter dual del poder occidental (Estado e Iglesia) encabezado por el emperador romano Constantino; es decir, las creencias religiosas de los cristianos del primer siglo se mezclaron con las creencias religiosas grecorromanas, estas conllevaron a la formación de la cultura religiosa occidental (Dawson, 1970; Weber, 2007). Por esta razón, Jung les reprochó a los protestantes europeos el haber suprimido los ritos de adoración a las imágenes "sagradas": "han perdido los más finos matices del cristianismo tradicional" (1981, p. 42).

El concepto de tecnología proviene de dos palabras griegas: "tekne ( $\tau \dot{\varepsilon} \chi \vee \eta)$ " que significa "saber", y la otra "logos ( $\lambda$ ó $\left.{ }^{\circ} \varsigma\right)$ " que significa "razón o tratado"; a partir de estos términos se entiende que la tecnología es la competencia intelectual para 
aplicar los conocimientos profundos o normativas de organización y proceder para resolver problemas o para "controlar y manipular" las cosas en el ambiente (Rubio y Esparza, 2016). Por su parte, el historiador, filósofo y sociólogo Michel Foucault entendió a los mecanismos de organización de poder como tecnologías; en este entendimiento alude también al poder de la Iglesia Católica del siglo XVI como una compleja red institucional que no solamente quería controlar a los humanos a nivel individual y colectivo, sino que también pretendía regir la conciencia humana, pero luego aparece una "nueva racionalidad política" donde acoge la organización de poder de la Iglesia (tecnologías pastorales) para encajarlo con otras tecnologías de poder (Permuy, 2015).

\section{Raza y racismo}

El concepto de "raza" ha llevado a la humanidad a varios conflictos hasta el extremo de genocidios inenarrables en la historia humana. Pese a todo ello, se sigue registrando en los textos como en el diccionario de la Real Academia Española (2014) el concepto de raza como "casta o calidad de origen o linaje". El concepto de "raza" no es otra cosa que las representaciones sociales de ambiente sociocultural e histórico que "flota" en los imaginarios colectivos y que está ligado especialmente a la clasificación o categorización de los seres humanos por el aspecto biológico externo o del color de la piel (que connota pureza o impureza de sangre) de las personas que configuran el estatus social y el poder; estas también han sido influenciadas por la teoría de la evolución (Oboler, 2015, del Olmo, 2003; Grosfogue, 2011; Quijano, 1992).

Entretanto, el racismo se entiende como la discriminación por causa de la superioridad de una "raza" sobre otras, basados especialmente en los rasgos físicos o biológicos (del Olmo, 2003; Maric. 2018). Grosfogue (2011) se refiere al "racismo epistémico" que clasificaba, influenciado por "cosmología cristiana", a los seres humanos considerados inferiores con "su cercanía a la animalidad (falta de racionalidad)" y solamente a las personas del Occidente se consideraba como seres racionales capaces de producir conocimiento.

\section{MÉTODO DEL ESTUDIO}

La investigación se ha abordado desde una perspectiva interdisciplinar, que parte de los elementos clave de la etnografía y de la antropología, pero que se refuerza con los aportes de otras perspectivas teóricas: psicología, comunicación, sociología y teorías de desarrollo humano.

En cuanto a las técnicas utilizadas para la recolección y análisis de datos, el enfoque ha sido de carácter cualitativo, desde una perspectiva flexible y abierta.

A partir de este concepto en el proceso de recolección de información, cada una de las técnicas cualitativas utilizadas tuvo que ser evaluada y reflexionada antes de ser aplicada en el trabajo de campo; además, cada una de ellas se manejó con la idea de complemento a otra técnica con la finalidad de profundizar los diferentes temas de la investigación.

\section{Participantes}

Todos los informantes (jóvenes, padres y profesores) proceden de la provincia de Moho, región Puno, Perú. Jóvenes que tenían edades comprendidas entre 15 y 29 años y todos ellos participaron directa o indirectamente en alguno de los proyectos de desarrollo llevados a cabo por el Instituto Peruano de Investigación Quechua Aymara JATHA MUHU, especialmente en el proyecto "Autogestión y liderazgo de jóvenes Aymara para el desarrollo comunal y local en Moho" (2009-2012).

También jóvenes adventistas fueron incluidos en el estudio para observar la influencia o no de las tradiciones católicas en sus representaciones sociales, porque los adventistas tienen creencias contrarias a las católicas: no creen ni adoran a las imágenes religiosas, rechazan las bebidas alcohólicas, pregonan el ascetismo religioso para ser llevado al cielo en la segunda venida de Jesucristo (Stahl, 2009; Núñez, 2008).

Así, como se ha expuesto al definir el ámbito del estudio, fueron seleccionados jóvenes según su confesión religiosa, repartidos al $50 \%$ entre católicos $\mathrm{y}$ adventistas. Cada grupo fue además dividido en dos grupos de edad: mayores de 20 años y menores de 20 años. Además, con la finalidad de complementar o interpretar las informaciones proporcionadas por jóvenes Aymara también se entrevistó a los padres, profesores y otras personas.

Los grupos de discusión tuvieron lugar en la zona Norte con 6 participantes y en la Sur de la provincia también con 6 participantes.

\section{Procedimiento}

Se utilizaron las siguientes técnicas cualitativas: 


\section{a) La observación participante}

Desde fines de 2009 a 2010 se procedió a observar y dialogar informalmente a jóvenes y padres de familias Aymara en el ámbito de ejecución del proyecto de desarrollo en las diferentes actividades que permitieron indagar en temas como la relación entre padres e hijos, prácticas religiosas fervientes en honor a los "santos" o "santas", poco interés de jóvenes en mejorar la producción y productividad agropecuaria (medio principal de sobrevivencia familiar), entre otros temas. Las informaciones obtenidas sirvieron para el planteamiento de problemas de investigación, elaboración de instrumentos y para la redacción de los resultados.

\section{b) Entrevista en profundidad}

En el presente trabajo de investigación se consideró conveniente analizar por medio de las entrevistas en profundidad en las temáticas surgidas a raíz de los indicios obtenidos en el proceso de observación participante. A tal efecto, se comenzó elaborando un repertorio de preguntas básicas acordes con los objetivos asignados a esta técnica de investigación. Al aplicar estos primeros instrumentos de recogida de datos en la zona de estudio, se obtuvo información que podría calificarse como preliminar.

Tras la evaluación de los datos obtenidos en las entrevistas de la prueba piloto, se consideró que era necesario elaborar un repertorio de preguntas más estructuradas para el conjunto de jóvenes. Para precisar mejor las preguntas que habrían de ser planteadas a jóvenes de las comunidades estudiadas, el autor principal de este estudio se valió del recuerdo y descripción pormenorizada de sus propias vivencias religiosas en el mundo andino, desde su infancia. Además, las preguntas elaboradas fueron aplicadas a una egresada de antropología que estuvo apoyando el trabajo en algunas de las tareas del proceso de investigación. La joven colaboradora mostraba su escepticismo respecto del vínculo entre las creencias religiosas y las actitudes relacionadas con el desarrollo humano. Ante esta resistencia, se entabló una conversación acerca de las experiencias religiosas de su entorno social y luego en el proceso se le iba preguntando también acerca de su papel en las mismas; y al final ella misma llegó a la conclusión que era ferviente católica. Y también en pos de seguir mejorando el repertorio de preguntas, se entrevistó en similar modo a otro joven egresado de la carrera profesional de antropología que se consideraba ajeno a las prácticas religiosas de su entorno.

Las experiencias de los informantes antes mencionados ayudaron a entender los modos de revelar de las personas acerca de sus creencias religiosas, ya que la gran mayoría de jóvenes Aymara suelen ser de por sí reservados y poco expresivos. Estas vivencias permitieron, además, precisar y enfocar mejor los temas que habrían de ser abordados en las entrevistas posteriores. Con el repertorio de preguntas abiertas y la estrategia conversacional así elaboradas se procedió luego a validar la herramienta entrevistando a tres jóvenes de la zona de la investigación para ajustar o perfilar mejor la formulación de algunas preguntas y fueran más fácilmente comprendidas por estos jóvenes Aymara. A partir de este cuestionario, también se elaboró otro más específico para los padres y para los profesores.

Una vez validadas las preguntas, se conformó un equipo de entrevistadores de cuatro personas (2 antropólogos y dos comunicadores) que gozaban de la confianza de jóvenes Aymara que iban a ser entrevistados. Previa capacitación, las entrevistas se ejecutaron en los propios hogares de los informantes en el transcurso de dos semanas.

\section{c) Grupos de discusión}

Luego de haber realizado las evaluaciones de cada una de las entrevistas en profundidad se observaron algunas ambigüedades en las informaciones proporcionadas por ciertos jóvenes en algunas preguntas. Por consiguiente, se determinó a la técnica de los "grupos de discusión" para profundizar en las preguntas. El total de jóvenes que participó en esta técnica no pertenecen a los grupos de las entrevistas de profundidad, pero tenían edades comprendidas entre 15 y 29 años y participantes también en los proyectos de desarrollo.

Para elaborar los instrumentos para el trabajo de campo se consideró conveniente, en un primer momento, realizar el grupo de discusión en la zona Sur. Sin embargo, luego de haber desarrollado el trabajo de campo en la mencionada zona, al revisar toda la información obtenida, esta pareció muy interesante para otros aspectos de la investigación, pero insuficiente o poco adecuada a los iniciales propósitos analíticos. Por esta razón, se acordó realizar otro grupo de discusión en la zona Norte, incrementando en algunas preguntas el guion de la dinámica y se estimó conveniente realizar una visita a 
algún templo católico. En los dos grupos de discusión se mantuvo el mismo criterio para la selección de sus integrantes (6 católicos y 6 adventistas).

En las dos ocasiones, el debate de los grupos de discusión se centró fundamentalmente en torno a la temática de racismo religioso. En los dos grupos de discusión a cada participante se le mostraron dos imágenes de Jesucristo del tamaño de una fotografía estándar; aunque ambas tenían las mismas características, a una de ellas se hizo un retoque de raza "blanca" a la "andina"; todas las demás características de la foto quedaron intactas. Luego se les pidió a los participantes de ambos grupos focales que escogieran una de ellas. Después de que los participantes hubieran seleccionado una de las imágenes que se le presentaron se procedió a plantearles a continuación algunas preguntas para la discusión.

\section{RESULTADOS}

\section{Niños y niñas Aymara idealizan las imágenes religiosas coloniales de "raza blanca"}

Así, en las entrevistas en profundidad, la mayoría de las respuestas se centra en que efectivamente percibieron las imágenes religiosas coloniales en la niñez junto con sus padres en diferentes espacios de la vida cotidiana. En ese sentido, en las fiestas patronales jóvenes Aymara, han tenido experiencias impactantes con las imágenes sacras, con algunas diferencias entre católicos y adventistas. Ya que los informantes conservan recuerdos vívidos de varios ritos: detonaciones de explosivos, procesiones de santos y santas con la acostumbrada resonancia musical, rezos, prenderles velas ante los santos o santas de "raza blanca", entre otros. Para ilustrar, la joven Marisoly (católica) ${ }^{5}$ en su niñez, en la fiesta patronal de su pueblo, se concentró en la imagen de Jesucristo crucificado: “'Así ha muerto (Jesús) en la cruz', me indicaba mi mamá. También a mí me importaba más mirar la cruz; todo el tiempo sé estar mirando". Además, niños y niñas Aymara curioseaban los rituales de otros devotos en las festividades, las sensaciones que les causaban los presagios de las velas prendidas como zozobra, felicidad y tristeza.

$\mathrm{Si}$ bien es cierto que los adventistas dicen no haber participado en los ritos a las "divinidades" durante su niñez, su curiosidad innata infantil les permitió percibir a las imágenes religiosas en las diferentes escenas festivas y sus rituales; ya que estas (ídolos) son un verdadero misterio y mágico para niños y niñas, porque es parte de su inocencia infantil, ilusionista, animista y antropomórfica. Así, Brinsthon (adventista), que en su niñez participó circunstancialmente en la festividad en honor a la Virgen Santa Rosa en la escuela de su hermano, donde los profesores la vestían, la cargaban y hasta la rezaban a la Virgen. Este niño Aymara al estar tan impresionado de las escenas se imaginaba acerca de la Virgen: "Pensaba que era una señora que estaba sentada. ¿Muerta será?, sé estar pensando...”.

En relación con la fiesta de la Navidad, estos jóvenes Aymara, durante su niñez, tienen recuerdos de un halo de magia, expectativas y esperas, felicidades y juegos, que los han marcado en su inconsciente, es más pronunciado en los adventistas que en los católicos.

Los rituales festivos, entonces, a menudo están vinculados a espacios sociales de gran intensidad o exaltación emocional y sentimental, en la práctica religiosa (tristeza, alegría, temor, llanto, culpa, dolor, compasión, etc.). Estas fuertes cargas emocionales y sentimentales favorecen la transferencia de poderes a los "ídolos" venerados en la representación de los participantes de las festividades especialmente de niños y niñas que les conlleva al apego a los mismos.

Asimismo, podemos inferir a partir de las manifestaciones de los informantes Aymara, la tendencia de cada niño y niña Aymara está en imitar las actitudes y comportamientos de sus progenitores (guías) en cuanto a las prácticas y expresiones para idealizar a las imágenes religiosas coloniales de "raza blanca" (ayudantes o protectoras), que fueron a su vez reforzados en estas prácticas por su entorno social y la escuela. Así, en el caso de una joven adventista en su niñez cuyo padre le reiteraba en su niñez no creer en santos o imágenes, ni bailar en honor de estos; pero ella recuerda también que ese mismo padre, por alguna razón, le llevaba a la fiesta en honor al "santo patrón"6.

Jóvenes Aymara reafirman su identidad hacia los ídolos religiosos coloniales

Jóvenes Aymara en la etapa de la adolescencia o juventud manifiestan la tendencia de reafirmar las prácticas de sus creencias religiosas coloniales aprehendidas en la infancia; por tanto, también reafirman su identidad con los íconos religiosos coloniales, con dominio de los fenotipos 
occidentales, no solamente como "símbolos orientadores de sus actitudes o conductas, sino que también de sus destinos". Ya que las imágenes son concebidas, en las Ciencias Sociales, generalmente como herramientas vitales para que las personas puedan "representar ideas complejas y abstractas" (Morris y Maisto, 2001).

Se pudo apreciar, por esta razón, que para jóvenes Aymara las festividades coloniales son espacios de atracción, distracción y diversión con algunas distinciones entre los católicos y adventistas, porque están imbricadas en el inconsciente colectivo con ciertas cargas emocionales. En ese sentido, jóvenes católicos no solamente consideran a las fiestas coloniales como escenarios agradables, sino que también son actores en las diferentes escenas. Para ilustrar, el joven Dominic revela: "Primero nos vamos a la misa y de ahí, después nos vamos a tomar (alcohol), compartir con los amigos, tranquilamente". Entretanto, jóvenes adventistas tienden a manifestar su agrado de algunas escenas festivas coloniales, pese a que en la Iglesia Adventista se considera a estas fiestas como paganas. De esta forma, para el entendimiento de Meladi (adventista), bailar en las fiestas no es pecado, sino el acto de beber alcohol.

\section{Las imágenes religiosas coloniales “idealizadas" procrean el racismo}

En las entrevistas en profundidad se verificaron en el imaginario de jóvenes Aymara del siglo XXI las características fisonómicas de las imágenes religiosas impuestas por la Iglesia Católica en el siglo $\mathrm{XVI}^{7}$. A este entender, se les preguntó, ¿cómo te imaginas a Jesús? Por consiguiente, la "piel blanca" de Jesucristo es el mayor foco de atracción para los jóvenes de ambos credos, algunos lo comparan con el color de la piel de los "gringos" (fisonomía de personas del Norte de Europa). Referente al cabello, existe una mayor inclinación de imaginar a Jesucristo con cabellos rubios que con negros y en similar modo, algunos informantes tienden a imaginar los ojos del personaje de color azul.

Los católicos tienen mayor inclinación de relacionar las imágenes de "raza blanca" con la santidad (pureza). Para ilustrar, las representaciones de dos jóvenes (Paola y Kahina) en cierto modo concuerdan con la de Epifanio. Kahina refiere que los santos "son hijos de Dios" y Paola que Jesús "es mandado por Dios". Estas afirmaciones refieren claramente que las imágenes de "raza blanca" son creadas o predestinadas por Dios para ser santas. En ese sentido, Karla refiere que la blancura de estas imágenes las hace santas: "Deben ser porque no tienen ningún pecado, porque el color blanco representa la paz y la pureza".

Los adventistas, entretanto, al tener mayor familiaridad con las imágenes de Jesucristo tienden a relacionar la "raza blanca (caucásica)" del personaje más con el poder que con la santidad. Como muestra, las afirmaciones de Lisbeth indican: "Eso es porque ellos tienen poder. Es que en todo el mundo los que tienen poder son blancos". Además, Caleb refiere que las imágenes de "raza blanca" son más atractivas para la gente; si estas fueran de rostro negro, las personas discriminarían por ser "feas".

No obstante, estas aseveraciones se consideraron insuficientes para fines del objetivo de estudio, por ello se recurrió a la técnica de los grupos de discusión.

En los dos grupos de discusión, a los jóvenes se les presentó dos imágenes físicas de Jesucristo: una de raza blanca con cabellos rubios y otra, trigueña (raza andina) con cabellos negros; aunque ambas son la misma foto, ya que a una de ellas se le hizo un retoque de blanca a andina (Figura 1). Luego de que los participantes de los dos grupos de discusión escogieran una de ellas, los resultados fueron los siguientes: de los 12 participantes ( 6 adventistas y 6 católicos), 9 escogieron la imagen de Jesucristo de raza blanca y 3 católicos escogieron la imagen de Jesucristo de raza andina.

Por un lado, se mantiene la elección de la imagen de Jesucristo de raza blanca. Los jóvenes adventistas de la zona Norte argumentan que han escogido esta imagen de Jesucristo porque les gusta los detalles de las características físicas; además, creen que les da "fortaleza", "consejo", "esperanza", "protección", que son propias del lenguaje de la cristiandad para asignar poder a los personajes divinos. Así como pone de manifiesto la joven adventista, Nieves: "A mí me gusta su corazón, sus ojos que son de color medio azulado, sus labios, sus cabellos medio rubios, su rostro y su cara que es de color blanco y tiene una cruz en el pecho".

Mientras sus pares (adventistas) de la zona Sur argumentaron que han elegido la foto de raza blanca de Jesucristo por ser "más clara o brillante": "Yo he escogido ese color, porque en este color se ve, tiene más brillo tiene. Me gusta que Cristo se vea más claro. Por ejemplo, en este canela (Cristo 
Figura 1

Fotografía de Jesucristo de raza andina y de raza blanca

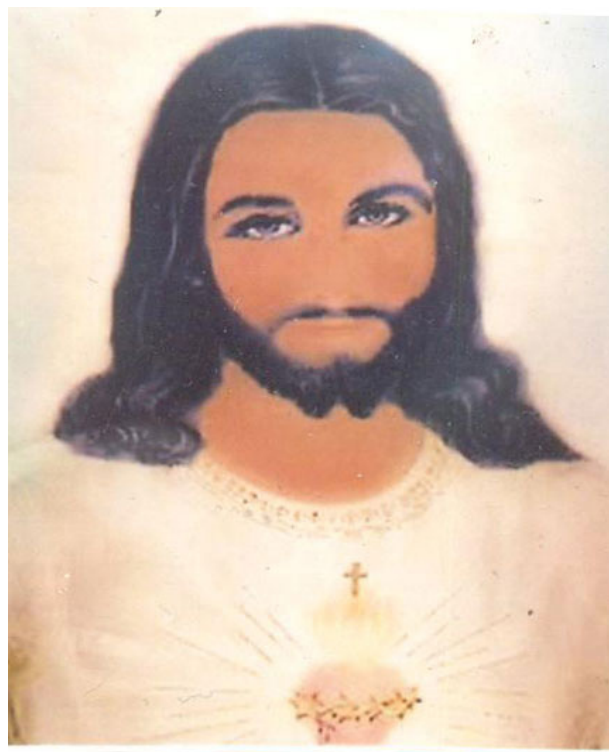

trigueño), no se ve bien, quiero que se extienda más la religión" (Robert, adventista).

Mientras tanto, los católicos de las zonas Norte y Sur aluden la elección de la imagen de Jesucristo de raza blanca, básicamente, porque es "más clara" que la imagen morena y para recibir "ayuda" y "protección". Al respecto, se intentó imponer la imagen trigueña de Jesucristo a Ludmir (católico) y su reacción ha sido de abstención: "También, pero más escogería de color blanco".

Por otro lado, los tres católicos son los únicos que han elegido la foto de Jesucristo de raza trigueña, dos de ellos tienen argumentos débiles: "para recibir ayuda" y "Jesucristo es moreno". Solamente el testimonio de Josely (católico) argumenta su elección a partir de la concepción que tiene de la discriminación: "Yo he escogido una de foto de Cristo un poco moreno... Pero nosotros pensamos que Cristo no discrimina a nadie..., por eso no debemos discriminar que es un Cristo blanco o Cristo moreno".

La perpetuación de la superioridad de la "raza blanca" causa complejo de inferioridad

Solamente a los participantes del grupo de discusión de la zona Norte, en el interior del templo,

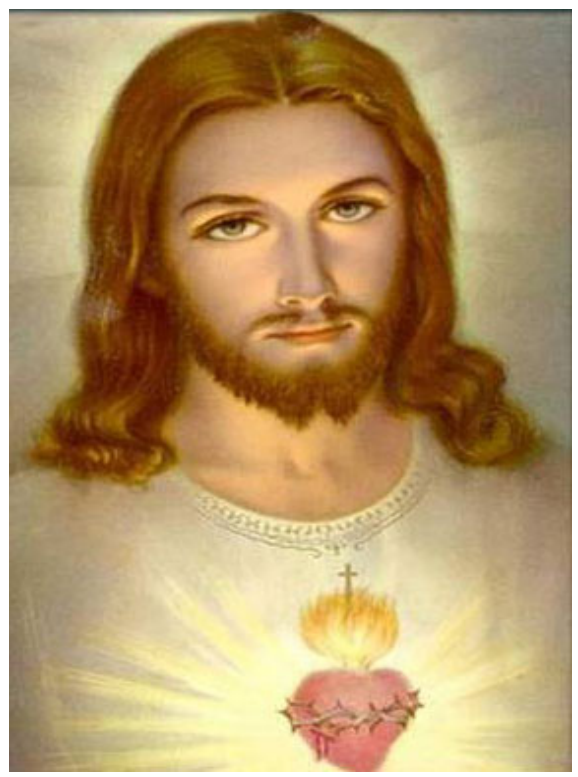

se les planteó la siguiente pregunta ¿tú crees que puede tener poder un santo con chullo? De las respuestas de los participantes se puede entender que las prendas de los Aymara pueden "contaminar o matar" la santidad y poder de las imágenes de "raza blanca". Según Ludmir (católico), en caso de colocar un chullo a un "santo" sus coterráneos considerarían que han matado a la imagen, en su concepción un "santo" tiene que ser "blanquito". Y para Nieves (adventista), el vestido de los "santos" es singular y no puede parecerse siquiera al de los Aymara.

Estos mismos jóvenes Aymara al estar en el interior del templo católico ante las imágenes coloniales manifestaron reacciones emotivas y encontradas, con mayor incidencia en los católicos que en los adventistas: "Cuando entro a una iglesia mi corazón late que tiene miedo cuando veo a esos diositos me pongo triste, a veces también alegre por todo lo que veo" (Lennon, adventista). Los adventistas exacerbaron sus sentimientos en medio de las imágenes, entre ellas la de Jesucristo; uno de ellos dijo: "una fortaleza blanca que entra en mi corazón, uhmm...", mientras que otro adventista relataba su turbación emocional: "pienso en mis pecados". Entretanto, los católicos parafrasearon: "me siento alegre", "siento esperanza para salir adelante", "tengo ganas de llorar", "confesar todo..." 
Como se puede apreciar, las imágenes católicas "ponen de manifiesto" su poder ante sus creyentes y son capaces de hacer revelar sus "pecados mejor guardados".

Por tanto, jóvenes Aymara tienden a considerar que a diferencia de personas de "raza blanca", sus coterráneos no tienen posibilidades de ser santos/as por ser pecadores y no tienen "poder" por ser débiles, tal como también han categorizado a la imagen de "Jesucristo de raza andina". Las respuestas de algunos jóvenes de la zona Norte han sido categóricas: "todos cometemos errores acá", "somos pecadores", "nosotros no tenemos poder". Mientras tanto, algunos participantes del grupo de discusión de la zona Sur solamente refieren que desde que tienen uso de la razón siempre han visto imágenes "divinas de raza blanca". En esta percepción inconsistente, Robert (adventista) afirma que las personas de raza blanca han sido "más perfectas".

Así, los participantes del grupo de discusión de la zona Norte manifiestan una crisis de identidad al estar frente a las imágenes católicas de raza blanca ("santos" y "santas") en el interior de un templo católico. Al respecto, Nieves (adventista), al fijarse en una Virgen, afirma que le gustaría tener su color de "piel" (belleza y poder) y su indumentaria (corona, ropa, collar). También, esta joven en otro momento refirió la razón por la que no escogió al Cristo de raza andina: "sería como el luto, (como) que alguien se muriera".

Por estas razones, en el altiplano peruano algunas mujeres cuentan historias, propias y ajenas, acerca del nacimiento de niños o niñas "blanquitas" por mirar a los santos o las Vírgenes. Algunos de los informantes del grupo de discusión de la zona Norte confirmaron las "historias de blanqueamiento". Así, Jocelyn (católica) refiere haber escuchado que las mujeres embarazadas que miran a una muñeca bonita (modelo Barbie) sus hijas nacen "igualitas", es decir, "blanquitas".

Los informantes del grupo de discusión de la zona Norte, del mismo modo, aseguran que sus coterráneos respetarían a un "gringo" por el solo hecho de ser de "raza blanca". Por el contrario, tres de ellos manifestaron que no les gustaría tener como prójimo a un "gringo" o "misti" porque los consideran malos y más listos; uno de ellos añade que odia al "misti".

No obstante, al entrar en razón jóvenes Aymara de ambas zonas, ante la pregunta, ¿por qué en las iglesias siempre encontramos santos o cristos blancos?, luego de un suspenso, se inclinaron en aludir el manejo de la religión por los países poderosos (España, Estados Unidos, Japón, Canadá) para dominar a los países pobres. Robert (adventistas) cambió su percepción anterior (su aprecio por la imagen de Jesús de "raza blanca"): "Los blancos dominan a la raza india..., fabrican a su color". Estos argumentos expresados por un sector de jóvenes, especialmente adventistas, no implican que hayan cambiado de sus percepciones originales, ya que las imágenes de "raza blanca" están representadas en su imaginario inconsciente.

Por todas las razones expuestas, se puede inferir en jóvenes Aymara una doble percepción de identidad racial: colonizados, cuando se someten a las imágenes religiosas coloniales y buscan el "blanqueamiento" para asemejarse a la raza de prestigio; y como colonizadores, cuando discriminan a la raza negra o a su propia raza. Además, esta conducta de doble personalidad racial representada en la mente, crea en los jóvenes una crisis de identidad que los conlleva a conflictos emocionales agravantes (angustia, vacío existencial, odio, etc.), esto es peor que la discriminación. Para ilustrar mejor este concepto, a continuación se presenta la manifestación del director de una institución educativa (ubicada en una de las zonas de estudio), profesor Nilo:

Ahora en el aspecto de raza ellos son más blanquiñosos, aunque en Estados Unidos no todos son blanquiñosos ¿no?... Entonces nosotros tenemos una raza que me parece que a nivel del mundo es la raza más mínima, es la peor ¿no? Discúlpenme que diga así y es la manera como vemos.

¿Por qué dice que es lo peor nuestra raza?

Mira viendo a nivel del mundo conociendo a tipos de razas, la raza chola que decimos de lo que soy yo, de lo que somos de esta raza un poquito..., no lo ven la gente del mundo, la sociedad del mundo con los buenos ojos ¿no? Nos consideran como cualquier o como cualquier ser ¿no? El ser más bajo, el ser más mínimo al vernos ¿no? Un ejemplito, vamos a Lima, llegamos a Lima y todo el mundo nos mira como negritos y cholos dicen ¿no? Y creo que ellos hablan así, por eso digo somos mal mirados. Aunque nosotros como profesores ya, yo siempre he dicho ¿no?, somos los mismos, tenemos dos ojos, tenemos 
dos pies todo tenemos lo mismo. Lo que nos diferencia de repente la parte del color nada más... Pero tal vez nosotros mismos somos culpables, viene un gringo lo miramos como un ser admirable ¿no? Viene un negro nosotros vamos a ver a otro sitio...

Además, el mismo profesor afirma que la discriminación entre sus estudiantes se materializa mediante la utilización de adjetivos como: "negro", "cholo", "feo". Lo que quiere decir que estos estudiantes discriminan contrastando su tonalidad piel como más blanca que el resto.

\section{La capacidad de las personas está en la condición de "raza"}

En algunos estudios en Ciencias Sociales, según Morris y Maisto (2001), se ha demostrado que se valora a las personas "bellas" como inteligentes, éticas y exitosas. En ese sentido, la mayor parte de jóvenes Aymara ${ }^{8}$ dan de entender que la capacidad de las personas está en la condición de "raza"; porque creen que la gente de "raza blanca" tiene dinero, tiene tecnología y es más inteligente. Por esta razón, consideran que los "gringos" tienen dominio en diferentes campos del desarrollo humano. En la lógica de considerar la naturalidad o predestinada de los "gringos" para ser "superiores", nada tiene que ver el esfuerzo de las personas: "fabrican las cosas", "tienen tecnología avanzada", "ellos tienen ganados mejorados", etc. Aunque algunos consideran que los "gringos" son superiores porque saquean a los países pobres.

Solamente un sector minoritario de jóvenes afirma que todas las personas son iguales, ya que la diferencia está en las cualidades desarrolladas. Entonces, se puede deducir que solo siendo de "raza blanca" se puede ser competitivo, poderoso, hasta divino; pero los pecaminosos (oscuros) no estarían a la altura para merecerlo.

\section{DISCUSIÓN Y CONCLUSIONES}

El presente estudio puso de manifiesto cómo la cultura racista de una sociedad contemporánea está sustentada en las "esencias" del pasado histórico religioso colonial. En ese sentido, se aprecia claramente cómo es que la Iglesia Católica ibérica junto con al poder político y militar desde la Edad Media empezó la construcción de la tecnología de poder fundamentada en la creencia de las imágenes de "raza blanca" consideradas sagradas y poderosas (símbolos de poder); esta tecnología en el proceso histórico iba configurando una compleja red institucional con el fin de controlar las almas de sus feligreses a nivel individual y a nivel colectivo (Permuy, 2015; del Olmo, 2003). Esta tecnología de poder se aplicó en el transcurso de la expulsión de los musulmanes y judíos del territorio ibérico, con la creencia de que estos tenían "impureza de sangre" y el color de la piel oscuro presuntamente basado en las doctrinas bíblicas (Caro, 1984; del Olmo, 2003).

Cuando los colonizadores invadieron el territorio de América, aplicaron una versión mejorada de la tecnología católica apoyado en el "poder" de los ídolos de raza blanca (connotan también pureza y calidad), estos han sido utilizados como modelos para las representaciones sociales de las identidades raciales (colonizadores "blancos" racionales versus colonizados "indios oscuros" irracionales), con lo que desarrollaron el control de la subjetividad (basado en los ídolos con "poder" y no en los principios bíblicos de liberación) de las almas de las personas originarias (representándose como seres "inferiores"); el control de la subjetividad justificaba la represión y el genocidio, sobre todo para la construcción de una nueva estructura de poder en los territorios conquistados (Suárez, 2012; Carrión, 2006; Quijano, 1992). Las consecuencias de esta realidad religiosa "oscura y de pobreza moral-espiritual", en particular para poblaciones han sido catastróficas como nos revela el presente estudio.

Según Allport (1954, 1963), las personas inmaduras tienen prejuicios y creencias superficiales (citado en J. Feist, y G. Feist 2007, p. 373). En ese sentido, la creencia de los colonizadores católicos de que la "raza blanca" ("pueblo con alma") es más cercana a la santidad no tiene sustento científico, ni tiene racionalidad o apoyo en las doctrinas de las Santas Escrituras. Al respecto, el antropólogo Kottar (2002: 81) afirma que la categorización de razas es una falacia, lo que ilustra con el siguiente ejemplo: "las personas 'blancas' son más rosadas, beige o morenas que blancas".

Ya que en la teoría de las Ciencias Sociales se afirma que en la infancia se da la rápida aculturación a partir de la adquisición del lenguaje (J. Feist, y F. Feist, 2007, p. 225). En este contexto, jóvenes Aymara, desde la edad infantil, en el proceso de aculturación, han sido partícipes en las tradiciones religiosas coloniales de sus progenitores con fuertes cargas emocionales; donde los ídolos religiosos de 
"raza blanca" son modelos "perfectos" de la concepción "irreversible" de lo "sagrado", "poder" y "belleza". Según Goleman (2005), las capacidades emocionales esenciales de las personas se forman en la niñez. Además, según Piaget (1991), los niños empiezan a descubrir y conceptuar a personajes como superiores (padres y otros adultos) en la relación vertical, donde se va configurando el respeto (compuesto de afecto y temor) por lo grande, fuerte y misterioso y también una sumisión inconsciente como irreversible y rígida.

¿Por qué jóvenes Aymara reafirman su identidad ante los ídolos coloniales? Según Jung (1981), las creencias en las imágenes "sagradas" como dogmas constituyen la expresión del alma más completa que cualquier teoría científica; por esta razón, considera a los ídolos "sagrados" como muros de salvaguardia y factores inconscientes importantes y reprocha a los protestantes por haber suprimido los ritos a estas imágenes. De modo que, en la etapa de la juventud y durante su proceso de reafirmación identitaria ${ }^{9}$, jóvenes Aymara han tenido como elementos centrales a las imágenes "divinas" de raza blanca de las tradiciones religiosas coloniales, idealizando sus características (estética $\mathrm{y}$ fenotipo occidental) hasta el punto de convertirse en sus referentes de poder y de éxito que les dan pie para tratar de resaltar la tonalidad blanca de su piel de manera exagerada, aunque los informantes en su racionalidad se reconocen como de la raza andina, con mayor predisposición los católicos que los adventistas.

En ese sentido, la tendencia de la creencia de jóvenes Aymara está en que las personas de "raza blanca" están "predestinadas" para ostentar capacidades en diferentes campos del desarrollo humano y ser hasta divinas ${ }^{10}$. De este modo, los jóvenes evidencian un trasfondo de la creencia en el destino occidental: las insuficientes capacidades de sus coterráneos para alcanzar el desarrollo humano por su condición de "raza andina" por ser "pecadores y débiles". Entonces, las taras racistas formadas en cerca de 500 años en el imaginario de la población originaria son muy difíciles de revertir. Ya que la tendencia racista hallado en el presente estudio concuerda con lo recogido en la primera encuesta nacional respecto de discriminación étnica-racial promovido por el Ministerio de Cultura de Perú (2018), donde se demuestra que el $53 \%$ de peruanos son racistas, que discriminan fundamentalmente por causa de color de piel o rasgos físicos (45\%) y el 59\% de los encuestados reconoce que los Aymara y Quechuas son discriminados o muy discriminados.

Por las razones expuestas, una gran mayoría de jóvenes de este estudio muestran estar sumidos en una crisis de identidad que lleva aparejado fuertes sentimientos de inferioridad debidos a su raza (andina) y que revierte en una permanente búsqueda del "blanqueamiento" como único medio de progreso. Al respecto, las emociones religiosas formadas, según Miró (2003), citando a Freud y Jung, refiere que someten a los feligreses a un mismo modo de comportarse hasta de forma anormal (cultura religiosa). Por tanto, las creencias religiosas coloniales han llevado a jóvenes Aymara a la sensación de inferioridad acompañado de un posible vacío existencial (desamparo, inconsistencia, inseguridad); además, estos sentimientos encontrados o contrapuestos son lo que les conducen a la "frustración permanente".

\section{DECLARACIÓN DE INTERESES}

Los autores declaran no presentar conflictos de interés en este estudio. 


\section{REFERENCIAS}

Baron, R. y Byrne, D. (2006). Psicología social. Pearson Educación S.A.

Bourdieu, P. (2006). La distinción, criterios y bases sociales del gusto. Santillana Ediciones Generales, S. L.

Caro, J. (1985). Formas complejas de la Vida Religiosa (religión, sociedad y carácter en la España de los siglos XVI y XVII). Sarpe.

Carrión, V. (2006). Pintura colonial y educación de la mirada: conformación de identidades y de la otredad. Revista Tabula Rasa, 4, 241-265.

Castellaro, M. (2011). El concepto de representación mental como fundamento epistemológico de la psicología. Revista de Filosofía y Psicología, 6(24), 55-67.

Del Olmo, J. M. (2003). Las caras del racismo. Libros en Red. https://www.indybay.org/uploads/2005/10/05/las_caras_del_racismo.pdf

Dawson, C. (1970). Los orígenes de Europa. RIALP.

Eliade, M. (1981). Lo sagrado y lo profano. Paidós

Guaman, F. (1980). Nueva corónica y buen gobierno I y II. Fondo de Cultura Económica.

Durkheim, E. (1968). Las formas elementales de la vida religiosa. Schapire.

Feist, J. y Feist, G. (2007). Teorías de la personalidad. McGraw-Hill.

Fernández, M. (2007). El concepto de creencia en el pragmatismo de Charles S. Peirce [Tesis de maestría, Universidad de Granada].

Galindo, M., Cruz, B., Pardo, E. y Bueno, R. (2007). Visiones aymaras sobre las autonomías. Aporte para la construcción del Estado nacional. Programa de Investigación Estratégica en Bolivia (PIEB).

Geertz, C. (1973). La interpretación de las culturas. Gedisa, S.A.

Goleman, D. (2005). La inteligencia emocional: por qué es más importante que el consciente intelectual. Javier Vergara Editor.

Grosfoguel, R. (2011). Racismo epistémico, islamofobia epistémica y ciencias sociales coloniales. Tabula Rasa, (14), 341-355.

Hervieu-Léger, D. (2005). La religión, hilo de memoria. Herder Editorial.

Jung, C. (1981). Psicología y religión. Paidós.

Klauer, A. (2000). El mundo pre-inka: los abismos del cóndor. Nueva Historia.

Klauer, A. (2000). Tahuantinsuyo: El cóndor herido de muerte. Nueva Historia.

Kottar, C. (2002). Antropología cultural. Universidad de Michigan.

Llanque, D. (1990). La cultura Aymara desestructuración o afirmación la identidad. TAREA Asociación de Publicaciones Educativas.

Mamani, B. (2003). Participación de los Padres y Madres de Familia en la Gestión Educativa Bilingüe en la Provincia de El Collao-Puno. Dirección Nacional de Educación Bilingüe Intercultural (DINEBI)

Mamani, B. (2004). Participación comunitaria en la gestión educativa bilingüe en las provincias Azángaro-Carabaya de la región Puno. DINEBI.
Maric, M. (2018). Estado de arte sobre imaginarios y representaciones sociales en Bolivia. En F. Aliaga, M. Maric, y C. Uribe (Eds.), Imaginarios y representaciones sociales. Estado de la Investigación en Iberoamérica (pp. 101-124). Ediciones USTA.

Mendieta, E. (s. f). Religión y Racismo en Latinoamérica. Universidad del Estado de New York.

Ministerio de Cultura del Perú (MCP) (2018). I Encuesta nacional percepciones y actitudes sobre diversidad cultural y discriminación étnica-racial. Ministerio de Cultura del Perú http://www.cultura.gob.pe/es/tags/encuesta-nacional-discriminacion-racismo-ipsos-diversidad-cultural

Miró, M. (2003). Emociones, sentimientos, experiencias y procesos religiosos. En E. Ardévol y G. Munilla (Eds.), Antropología de la religión (pp. 325-400). UOC.

Montoya, R. (1990). Por una educación bilingüe en el Perú. Reflexiones sobre Cultura y Socialismo. CESPES.

Morris, C. y Maisto, A. (2001). Psicología Social. Pearson educación

Murra, J. (2002). El mundo andino: Población, medio ambiente y economía. IEP- PUCP.

Muzam, J. (2010). Racismo iconográfico en la Iglesia Católica. Hispanic L.A. http://www.hispanicla.com/ racismo-iconografico-en-la-iglesia-catolica-3-7533

Núñez, H. (2008). Presencia protestante en el altiplano peruano. Puno, 1898-1915. El caso de los Adventistas del Séptimo Día: actores y conflictos (Tesis para obtener el título en Antropología, Universidad Nacional Mayor de San Marcos).

Oboler, S. (2015). Raza etnia, nación y ciudadanía en el imaginario de las Américas. En S. Oboler y J. Callirgos (Eds.), Racismo Peruano (pp. 15-45). Ministerio de Cultura. https://centroderecursos.cultura.pe/sites/default/files/rb/pdf/el-racismo-peruano.pdf

Oficina del Alto Comisionado de la Naciones Unidas para los Derechos Humanos (ACNUDH) (2003). Las dimensiones del racismo. ANUDH. https://www.ohchr.org/documents/publications/dimensionsracismsp.pdf

Papalia, D., Wendkos, S. y Duskin, R. (2009). Psicología del desarrollo de la infancia a la adolescencia. McGraw-Hill.

Permuy, E. (2015). Las tecnologías de poder de Foucault y el control de la migración [Tesis de maestría, Universidad de Barcelona]. http://diposit.ub.edu/dspace/bitstream/2445/67945/1/ TFM_belen\%20permuy.pdf

Piaget, J. (1991). Seis estudios de psicología. Labor.

Quijano, A. (1992). Colonialidad y modernidad/racionalidad. Perú indígena, 29, 11-20.

Real Academia Española (RAE) (2014). Diccionario de la lengua española. Real Academia Española.

Robins, N. (2009). Comunidad, clero y conflictos: las relaciones entre la curia y los indios en el Alto Perú, 1750-1780. Plural.

Rostworowski, M. (2007). Estructuras andinas del poder Ideología religiosa y política. IEP.

Rossi, M. A. (2015). La decadencia del Imperio romano desde la perspectiva de Agustín de Hipona. Circe, 19, 33-53. 
Rubio, E. y Esparza, R. (2016). ¿Qué es Tecnología? Una aproximación desde la Filosofía: Disertación en dos movimientos. Revista humanidades, 6(1), 1-43.

Sánchez, G. (2003). La imagen como método de evangelización en la Nueva España: los catecismos pictográficos del siglo XVI: fuentes del conocimiento para el restaurador [Tesis de doctorado, Universidad Complutense de Madrid]. http://biblioteca.ucm.es/ tesis/bba/ucm-t26810.pdf

Santa Biblia (1960). Versión Reina Valera. Sociedades Bíblicas Unidas.

Silva, J., Corona, R. y Herrera, Na. (2017). Creencias hacia el origen de la vida y naturaleza humana: Una comparación entre académicos de universidades públicas y privadas. Revista Integración Académica en Psicología, 5(13), 107-120.

Stahl, F. (2009). En el país de los Incas. Asociación Casa Editora Sudamericana.

Suárez, M. (2012). Inquisición y Limpieza de Sangre en Nueva España: 1571-1623 [Tesis de maestría, Universidad Cantabria]. https://repositorio.unican.es/xmlui/bitstream/
handle/10902/1481/Su\%C3\%A1rez\%20Ruiz\%2C\%20 Mar\%C3\%ADa.pdf?sequence $=1 \&$ isAllowed $=y$

Strocka, G. (2008). Unidos nos hacemos respetar: jóvenes, identidades y violencia en Ayacucho. UNICEF.

Uribe, C., Ramírez, C., Aliaga, F. y Rojas, S. (2018). La producción científica sobre imaginarios sociales en Colombia, 2005-2016. Un estado de la cuestión. En F. Aliaga, M. Maric, y C. Uribe (Eds.), Imaginarios y representaciones sociales. Estado de la Investigación en Iberoamérica (pp. 189-222). Ediciones USTA.

Vera, P. (2018). Interrogar sentidos desde las ciencias sociales. Una aproximación a los estudios actuales sobre imaginarios y representaciones sociales en Argentina. En F. Aliaga, M. Maric, y C. Uribe (Eds.), Imaginarios y representaciones sociales. Estado de la Investigación en Iberoamérica (pp. 21-100) Ediciones USTA.

Vinatea, M. (2018). Francisco Pizarro, el héroe hacedor de mitos. Revista Hipogrifo, 6, 217-226.

Wachtel, N. (1976). "Los vencidos": Los indios del Perú frente a la conquista española (1530-1570). Alianza Editorial.

Weber, M. (2004). La ética protestante. Gráfico. 


\section{NOTAS}

1 Los feligreses ibéricos medievales se afanaban por obtener el título de "sangre limpia" para presumir sus "cualidades morales cristianas" hasta para la distinción de clases sociales (nobleza, hidalgo y plebeyo) y no trabajar en actividades duras (agrícola, artesanal o mercantil) (del Olmo 2003 y Suárez 2012).

$2 \quad$ Vivian Marcela Carrión Barrero analizó las pinturas de los santos como portadores de discurso entre colonizadores y colonizados titulados: Pintura colonial y educación de la mirada (conformación de identidades y de la otredad), publicado en Tabula Rosa. Bogotá-Colombia, Nro 4: 241-265, 2006.

3 Las imágenes coloniales se elaboraron en Colombia en el auge del mestizaje como símbolos para la colonización de las mentes de los pueblos originarios, donde se naturaliza la dominación de los "colonizadores blancos" sobre los "colonizados oscuros".

4 Nicholas A. Robins a partir de sus investigaciones realizadas en los documentos coloniales del Archivo y Biblioteca Arquidiocesano "Monseñor Taborga" de La Paz y en el Archivo y Biblioteca Nacional de Bolivia, publicó el libro titulado: Comunidad, clero y conflicto, las relaciones entre la curia y los indios en el Alto Perú, 1750-1780, donde relata también ciertas atrocidades de la curia colonial en las zonas del presente estudio como el fomento de la borrachera en las fiestas patronales para sacar réditos económicos y satisfacer sus apetitos promiscuos.

$5 \quad$ Se cambiaron los nombres de todos los informantes en el estudio.

6 En las Ciencias Sociales está comprobado que los niños/as, a menudo, aprenden a hacer lo que sus padres hacen y no lo que dicen (Baron y Byrne 2005).

$7 \quad$ Esta aseveración se sustenta en la disposición de la Iglesia Católica del siglo XVI para la creación artística de las imágenes religiosas con característica fenotípica caucásica occidental (condición social, ropas, gesto y actitud) como representación de la "dignidad y santidad" (Sánchez 2003).

8 Los informantes al creer que las imágenes religiosas son "bellas" y "poderosas" tienden a tener como referente a estas para valorar o discriminar a las personas.

9 Según Bourdieu (2006), la herencia material (imágenes religiosas) es a la vez herencia cultural que consagra la identidad social de una clase social.

10 La cultura religiosa formada en cerca de 500 años, los feligreses de generación a generación siempre estarán en disposición de tener como referentes a modelos con imágenes de "raza blanca" para discriminar o valorar a las personas (Durkheim 1968; Geertz 1973; Jung 1981; Bourdieu 1997). 